\title{
Monilinia Species Associated with Brown Rot of Cultivated Apple and Pear Fruit in China
}

Xiao-Qiong Zhu and Cheng-Wang Niu, Department of Plant Pathology, China Agricultural University, Beijing, 100193; Xiao-Yu Chen, Beijing Plant Protection Station, Beijing, 100029; and Li-Yun Guo, Department of Plant Pathology, China Agricultural University, Beijing

\begin{abstract}
Zhu, X.-Q., Niu, C.-W., Chen, X.-Y., and Guo, L.-Y. 2016. Monilinia species associated with brown rot of cultivated apple and pear fruit in China. Plant Dis. 100:2240-2250.

Monilinia isolates were collected from major apple and pear production regions in China from 2004 to 2011 and identified based on their morphological characteristics and three highly conserved loci. The 247 isolates belonged to three species: Monilinia fructicola, Monilia yunnanensis, and Monilia polystroma. M. yunnanensis was the most prevalent (77\%), followed by M. polystroma (20\%) and Monilinia fructicola (3\%). Monilia yunnanensis is primarily distributed in the south, north, and west of China; M. polystroma is limited to the north and east; and Monilinia fructicola was detected only from a few samples from the north and east. Phylogenetic analysis based on internal transcribed spacer, $\beta$-tubulin, and laccase (lcc2) genes suggested that Monilia yunnanensis, M. polystroma, and

Monilinia fructigena are closely related, and Monilia yunnanensis is more distantly related. We also found that these three species do not show consistent differences in morphological characteristics, including colony morphology, colony expansion rate, conidial characteristics, and the amount of stroma produced in culture. Thus, these three species are more like phylogenetic species in the process of speciation. In addition, a set of species-specific primers based on single-nucleotide polymorphisms and deletions in the $l c c 2$ gene region were designed and a conventional polymerase chain reaction method successfully developed for differentiating Monilinia fructicola, Monilia yunnanensis, M. polystroma, and Monilinia laxa from the other species.
\end{abstract}

Brown rot is one of the most economically important diseases of Malus spp. Mill. and Pyrus communis L., causing severe yield losses at pre- and postharvest stages (Byrde and Willetts 1977). Brown rot, caused by Monilinia spp., not only affects the fruit but also causes blossom and leaf blight (Berrie and Holb 2014; Byrde and Willetts 1977). In Europe, preharvest losses from 7 to $25 \%$ were found in conventional and organic apple orchards, respectively (Berrie and Holb 2014).

To date, six closely related species of brown rot fungi have been reported on stone and pome fruit, including Monilinia fructicola (G. Winter) Honey, M. laxa (Aderh. \& Ruhland) Honey, M. fructigena Honey, Monilia polystroma G. C. M. van Leeuwen, M. yunnanensis M. J. Hu \& C. X. Luo, and M. mumecola Y. Harada, Y. Sasaki \& T. Sano (Byrde and Willetts 1977; Harada et al. 2004; Hu et al. 2011; van Leeuwen et al. 2002). The geographic distribution of these species differs across the world. Monilinia laxa is commonly found in many places worldwide. M. fructigena is mostly restricted to European countries. M. fructicola used to be documented mainly in America and New Zealand but it was recently found in southern France (OEPP/EPPO 2002), Hungary (Petróczy and Palkovics 2006), Switzerland (Bosshard et al. 2006), the Czech Republic (Duchoslavová et al. 2007), Spain (De Cal et al. 2009), Italy (Pellegrino et al. 2009), Slovenia (Munda and Marn 2010), Germany (Grabke et al. 2011), Switzerland (Hilber-Bodmer et al. 2010), Serbia (Vasić et al. 2012), Poland (Poniatowska et al. 2013), several regions in China (Hu et al. 2011; Yin et al. 2015; Zhu et al. 2005, 2011), and, recently, on apple in Pennsylvania (Peter et al. 2015). Monilia polystroma, a species closely related to Monilinia fructigena, was first described in Japan (van Leeuwen et al. 2002) and then reported in Hungary

\section{Corresponding author: L. Y. Guo; E-mail: ppguo@cau.edu.cn}

*The $\boldsymbol{e}$-Xtra logo stands for "electronic extra" and indicates that four supplementary figures are published online.

Accepted for publication 14 June 2016.

http://dx.doi.org/10.1094/PDIS-03-16-0325-RE

(C) 2016 The American Phytopathological Society
(Petróczy and Palkovics 2009; Petróczy et al. 2012), China (Zhu and Guo 2010), Croatia (Di Francesco et al. 2015), and Slovenia (Munda 2015). Monilia yunnanensis (Hu et al. 2011), closely related to Monilinia fructigena (Zhu et al. 2011), was recently found in China. Monilia mumecola, another newly identified species, was first found in Japan (Harada et al. 2004) and was detected recently in China (Hu et al. 2011; Yin et al. 2014, 2015).

China has the world's largest pome fruit industry. In 2013, apple production was about 40 million metric tons and pear production was about 17 million metric tons, accounting for 50 and $69 \%$ of the world's total yield, respectively (http://faostat3.fao.org/download/ Q/QC/E). In recent studies, five species (Monilinia fructicola, Monilia yunnanensis, M. polystroma, M. mumecola, and Monilinia laxa) have been found on stone fruit in China (Fan et al. 2010; Hu et al. 2011; Yin et al. 2014; Zhu et al. 2011), suggesting that the population structure of brown rot fungi in this region is more complex than previously recognized (Zhu et al. 2008). However, little is known about the species composition of brown rot fungi on apple and pear in China. Furthermore, previous research has shown that brown rot pathogens have a certain degree of host specificity (Byrde and Willetts 1977). For example, $M$. fructicola mainly infects peach and nectarine, $M$. fructigena commonly attacks apple and pear, and $M$. laxa frequently occurs on apricot (EPPO/CABI 1997). Therefore, it is possible that the species composition of brown rot fungi on apple and pear in China is different from that on stone fruit.

Historically, Monilinia spp. have been differentiated based on morphological and cultural methods (Byrde and Willetts 1977; van Leeuwen and van Kesteren 1998). However, morphological characteristics vary with growth conditions and often are not reliable enough to be used in routine species-level identification. As a result, several polymerase chain reaction (PCR)-based methods have been established to identify Monilinia spp. according to sequence differences in markers such as simple-sequence repeats (Ma et al. 2003), random amplified polymorphic DNA (Cote et al. 2004; Gell et al. 2007), and some gene regions such as internal transcribed spacer (ITS) regions 1 and 2 (Gell et al. 2007; Ioos and Frey 2000), $\beta$-tubulin (TUB) (Fan et al. 2014; Hu et al. 2011; Ma et al. 2003), and the cytbI gene (Hily et al. 2011; Miessner and Stammler 2010). However, because of the recent discovery of new species and the fact that the sequence differences of these Monilinia spp. are restricted to 
Table 1. Isolates used for multigene analysis and morphological characterization ${ }^{\mathrm{x}}$

\begin{tabular}{|c|c|c|c|c|c|c|c|}
\hline \multirow[b]{2}{*}{ Isolates, species } & \multirow[b]{2}{*}{ Isolate } & \multirow[b]{2}{*}{ Location } & \multirow[b]{2}{*}{ Host } & \multirow[b]{2}{*}{ Year } & \multicolumn{3}{|c|}{ GenBank accession number } \\
\hline & & & & & ITS & $T U B$ & $l c c 2$ \\
\hline \multicolumn{8}{|l|}{ This study } \\
\hline Monilinia fructicola & LS19-1 $1^{\mathrm{y}, \mathrm{z}}$ & Laiyang, Shandong & Apple & 2006 & KR778925 & KR778963 & KT194355 \\
\hline M. fructicola & $\mathrm{MX} 4^{\mathrm{y}}$ & Laiyang, Shandong & Apple & 2006 & KR778926 & KR778964 & KT194356 \\
\hline M. fructicola & $\mathrm{LBF}^{\mathrm{y}}$ & Fangshan, Beijing & Pear & 2005 & KR778927 & KR778965 & KT194357 \\
\hline M. fructicola & SPL6 ${ }^{y}$ & Pingyi, Shandong & Pear & 2007 & KR778928 & KR778962 & KT194358 \\
\hline M. fructicola & $\mathrm{CX} 27-1^{\mathrm{y}, \mathrm{z}}$ & Laiyang, Shandong & Pear & 2006 & KR778929 & KR778966 & KT194359 \\
\hline M. fructicola & $\mathrm{MX5}^{\mathrm{y}}$ & Laiyang, Shandong & Pear & 2006 & KR778930 & KR778967 & KT194360 \\
\hline M. fructicola & SY4y & Laiyang, Shandong & Pear & 2006 & KR778931 & KR778968 & KT194361 \\
\hline Monilia polystroma & $\mathrm{SDA} 2^{\mathrm{y}, \mathrm{z}}$ & Shandong & Apple & 2004 & KR778903 & KR778941 & KT194334 \\
\hline M. polystroma & SXP1y & Yiyuan, Shandong & Apple & 2007 & KR778904 & KR778942 & KT194335 \\
\hline M. polystroma & LS10-2y & Laiyang, Shandong & Apple & 2006 & KR778905 & KR778943 & KT194336 \\
\hline M. polystroma & $\mathrm{LHX}^{\mathrm{y}, \mathrm{z}}$ & Xinji, Hebei & Pear & 2005 & KR778906 & KR778944 & KT194337 \\
\hline M. polystroma & $\mathrm{MX} 2^{\mathrm{y}}$ & Laiyang, Shandong & Pear & 2006 & KR778907 & KR778945 & KT194338 \\
\hline M. polystroma & SXL-1-1 ${ }^{\mathrm{y}}$ & Taian, Shandong & Pear & 2007 & KR778908 & KR778946 & KT194339 \\
\hline M. polystroma & SY3 ${ }^{y}$ & Laiyang, Shandong & Pear & 2006 & KR778909 & KR778947 & KT194340 \\
\hline M. yunnanensis & $\mathrm{ABC} 1^{\mathrm{y}}$ & Changpin, Beijing & Apple & 2005 & KR778910 & KR778948 & KT194341 \\
\hline M. yunnanensis & $\mathrm{ASJ} 1^{\mathrm{y}}$ & Jugong, Shaanxi & Apple & 2005 & KR778911 & KR778949 & KT194342 \\
\hline M. yunnanensis & $\operatorname{AST} 1^{y, z}$ & Taiyukou, Shaanxi & Apple & 2005 & KR778912 & KR778950 & ND \\
\hline M. yunnanensis & BJCC2-1y & Baoji, Shaanxi & Apple & 2006 & KR778913 & KR778951 & KT194343 \\
\hline M. yunnanensis & CLA3-1y & Changli, Hebei & Apple & 2006 & KR778914 & KR778952 & KT194344 \\
\hline M. yunnanensis & YN1-2-02 $2^{y, z}$ & Zhaotong, Yunnan & Apple & 2006 & KR778915 & KR778953 & KT194345 \\
\hline M. yunnanensis & YS1-1 ${ }^{\mathrm{y}}$ & Yongshou, Shaanxi & Apple & 2006 & KR778916 & KR778954 & KT194346 \\
\hline M. yunnanensis & BCB-1 $1^{y}$ & Changping, Beijing & Pear & 2006 & KR778917 & KR778955 & KT194347 \\
\hline M. yunnanensis & CLP26 $6^{y}$ & Changli, Hebei & Pear & 2006 & KR778918 & KR778956 & KT194348 \\
\hline M. yunnanensis & $\mathrm{GX} 32^{\mathrm{y}}$ & Yanqing, Beijing & Pear & 2005 & KR778919 & KR778957 & KT194349 \\
\hline M. yunnanensis & JC-LH-9y & Jingchuan, Gansu & Pear & 2007 & KR778920 & ND & KT194350 \\
\hline M. yunnanensis & $\mathrm{LBD}^{\mathrm{y}, \mathrm{z}}$ & Daxing, Beijing & Pear & 2005 & KR778921 & KR778958 & KT194351 \\
\hline M. yunnanensis & LBH1-1y & Haidian, Beijing & Pear & 2005 & KR778922 & KR778959 & KT194352 \\
\hline M. yunnanensis & LSB $1^{y}$ & Binxian, Shaanxi & Pear & 2005 & KR778923 & KR778960 & KT194353 \\
\hline M. yunnanensis & YXS4y,z & Lanzhou, Gansu & Pear & 2007 & KR778924 & KR778961 & KT194354 \\
\hline M. yunnanensis & AK9-1 & Akesu, Xinjiang & Apple & 2011 & KR778935 & KR778977 & KT194371 \\
\hline M. yunnanensis & AL2-1 & Akesu, Xinjiang & Pear & 2011 & KR778936 & KR778978 & KT194372 \\
\hline M. yunnanensis & WS8-2 & Alaer, Xinjiang & Apple & 2011 & KR778934 & KR778976 & KT194370 \\
\hline M. polystroma & $M W 2^{y}$ & Laiyang, Shandong & Apple & 2006 & KR778902 & KR778940 & KT194333 \\
\hline \multicolumn{8}{|l|}{ Reference } \\
\hline Monilinia fructicola & $\mathrm{Ft}^{\mathrm{y}, \mathrm{z}}$ & France & N/A & N/A & HQ846967 & KR778979 & KT194373 \\
\hline M. fructicola & NE18y & New Zealand & N/A & N/A & HQ846919 & KR778980 & KT194374 \\
\hline M. fructicola & LVN8y & USA & N/A & N/A & HQ846966 & KR778981 & KT194375 \\
\hline M. fructigena & EA-1 $1^{\mathrm{y}, \mathrm{z}}$ & United Kingdom & N/A & N/A & ND & ND & KT194364 \\
\hline M. fructigena & CBS101500y,z & Poland & N/A & N/A & KR778933 & KR778973 & KT194365 \\
\hline M. fructigena & CBS101499y,z & Spain & N/A & N/A & KR778932 & KR778974 & KT194368 \\
\hline M. fructigena & EP-5 $5^{\mathrm{y}, \mathrm{z}}$ & United Kingdom & N/A & N/A & ND & KR778975 & KT194369 \\
\hline M. fructigena & $\mathrm{A} 2^{\mathrm{y}, \mathrm{z}}$ & France & N/A & N/A & ND & ND & ND \\
\hline M. fructigena & $\mathrm{P} 1^{\mathrm{y}}$ & France & N/A & N/A & HQ846946 & KR778982 & KT194376 \\
\hline M. fructigena & GENA4y & Italy & N/A & N/A & HQ846945 & ND & ND \\
\hline M. laxa & $\mathrm{P}^{\mathrm{y}, \mathrm{z}}$ & France & N/A & N/A & HQ846947 & KR778983 & KT194377 \\
\hline M. laxa & CBS298.31 y & Ireland & N/A & N/A & HQ846949 & KR778984 & KT194378 \\
\hline M. laxa & MDA12y & United States & N/A & N/A & HQ846948 & KR778985 & KT194379 \\
\hline Monilia mumecola & ML-1a & Wuhan, Hubei & Peach & 2008 & HQ908786 & N/A & N/A \\
\hline M. mumecola & HXL10-1a & Xiangfan, Hubei & Nectarine & 2010 & HQ908787 & N/A & N/A \\
\hline M. mumecola & HWL10-13b & Wuhan, Hubei & Peach & 2010 & N/A & HQ908775 & N/A \\
\hline M. mumecola & HWL10-1b & Wuhan, Hubei & Peach & 2010 & N/A & HQ908774 & N/A \\
\hline M. polystroma & HML $3^{\mathrm{y}, \mathrm{z}}$ & Mudanjiang, Heilongjiang & Plum & 2008 & GU067539 & KR778970 & KT194363 \\
\hline M. polystroma & $\mathrm{CBS} 102686^{\mathrm{y}, \mathrm{z}}$ & Japan & N/A & N/A & HQ846944 & KR778971 & KT194366 \\
\hline M. polystroma & $2319^{y, z}$ & Japan & N/A & N/A & HQ856916 & KR778972 & KT194367 \\
\hline M. yunnanensis & $\mathrm{GP} 18^{\mathrm{y}, \mathrm{z}}$ & Yanqing, Beijing & Peach & 2005 & HQ856917 & KR778969 & KT194362 \\
\hline Monilinia fructicola & XP1 & Chaoyang, Beijing & Peach & 2005 & KR778937 & ND & ND \\
\hline Monilia yunnanensis & KY-1 & Kaiyuan, Yunnan & Peach & 2009 & HQ908788 & ND & N/A \\
\hline M. yunnanensis & YKG10-61c & Kunming, Yunnan & Peach & 2010 & N/A & HQ908773 & N/A \\
\hline Sclerotinia sclerotiorum & HAY30y & Unknown & Rape & N/A & HQ846942 & KR778938 & KT194381 \\
\hline Botrytis cinerea & BCE4y & Beijing & Tomato & N/A & HQ846943 & KR778939 & KT194380 \\
\hline
\end{tabular}

${ }^{\mathrm{x}}$ ITS $=$ internal transcribed spacer, $T U B=\beta$-tubulin, $l c c 2=$ laccase, N/A $=$ not available, and ND $=$ not determined.

y Isolates used for multigene analysis.

${ }^{\mathrm{z}}$ Isolates used for morphological characterization. 
a small region on these genes, none of the reported methods has been able to differentiate all six related Monilinia spp. mentioned above.

Therefore, the objectives of this study were to (i) identify the species of brown rot fungi associated with apple and pear based on molecular and morphological methods, (ii) determine their pathogenicity on apple, and (iii) develop a PCR-based method to differentiate Monilinia spp.

\section{Materials and Methods}

Fungal isolates. Diseased apple and pear fruit with typical brown rot symptoms were collected mostly from orchards located in major production areas in China from 2004 to 2011. Fungi were isolated and preserved following the method described by Zhu et al. (2011). Specifically, a sterilized wire loop was used to transfer conidia from the fruit (or mummy) onto the surface of water agar (WA) in petri dishes. After 16 to $24 \mathrm{~h}$ at $22 \pm 2{ }^{\circ} \mathrm{C}$, individual germinated conidia were aseptically transferred with the aid of a dissecting microscope from the WA to potato dextrose agar (PDA) in petri dishes. The isolates were then stored on PDA slants at $4{ }^{\circ} \mathrm{C}$, and representative cultures were deposited in the Mycology Lab of China Agricultural University. In addition, some previously identified isolates and reference isolates of $M$. fructicola, $M$. fructigena, M. laxa, Monilia polystroma, M. yunnanensis, and M. mumecola were used in this study (Table 1).

DNA extraction, PCR amplification, and sequencing. Mycelia grown in pea broth at $22 \pm 2{ }^{\circ} \mathrm{C}$ for 5 to 7 days in darkness were collected by filtration and used for DNA extraction following the method described by Zhu et al. (2011). The ITS regions, including ITS1, ITS2, and the 5.8S ribosomal RNA gene of ribosomal DNA, were amplified using primers ITS1/ITS4 (White and Bruns 1990). Part of the $T U B$ gene was amplified using primers $\mathrm{Bt} 2 \mathrm{a} / \mathrm{Bt} 2 \mathrm{~b}$ (Glass and Donaldson 1995). A partial laccase gene (lcc2) was amplified using primers LacaF/LacaR developed in this study, based on gene sequences of $l c c 2$ from Hirschhäuser and Fröhlich (2007) (Table 2). The PCR of ITS, TUB, and $l c c 2$ was performed in a $50-\mu l$ volume containing $200 \mu \mathrm{M}$ each $\mathrm{dNTP}, 0.2 \mu \mathrm{M}$ respective primers, $2.0 \mathrm{mM} \mathrm{MgCl}$, $2.0 \mathrm{U}$ of Taq polymerase (CNS Bioservices Co. Ltd.), and 20 to $40 \mathrm{ng}$ of genomic DNA. PCR cycling parameters were $94^{\circ} \mathrm{C}$ for $3 \mathrm{~min}$; followed by 30 cycles of $94^{\circ} \mathrm{C}$ for $30 \mathrm{~s}, 50$ to $55^{\circ} \mathrm{C}$ for $30 \mathrm{~s}$, and $72^{\circ} \mathrm{C}$ for $1.5 \mathrm{~min}$; and a final $72^{\circ} \mathrm{C}$ for $10 \mathrm{~min}$ in an Icycler Thermal Cycler (Bio-Rad Laboratories Inc.). PCR products were separated by electrophoresis in $1.5 \%$ agarose gels in Tris-borate-EDTA buffer and were photographed with a Multilmage Light Cabinet (Alpha Innotech Corporation) after staining with ethidium bromide. The amplified fragments were purified using the PCR product Purification Kit (Dingguo Inc.) and both strands were sequenced using the PCR primers by Beijing Sunbiotech Co. Ltd. The nucleotide sequences were read with software Bioedit 7.0.4.1 (Hall 2011). Consensus sequences obtained in this study were deposited in GenBank (Table 1).

Species-specific primers design. Sequences of $T U B$ and $l c c 2$ genes of test isolates were aligned and compared using DNAMAN 7 (Lynnon Corporation). Primer pairs ClaF/ClaR, LlaF/LlaR,

Table 3. Rate of lesion expansion caused by Monilinia fructicola, $M$. fructigena, Monilia yunnanensis, and M. polystroma on apple between the second and fourth day after inoculation

\begin{tabular}{|c|c|c|c|c|}
\hline \multirow[b]{2}{*}{ Species, isolate } & \multirow[b]{2}{*}{ Host $^{\mathrm{z}}$} & \multirow[b]{2}{*}{ Location } & \multicolumn{2}{|c|}{$\begin{array}{l}\text { Expansion rate } \\
\left(\mathbf{m m} \text { day }^{-1}\right)^{\mathbf{y}}\end{array}$} \\
\hline & & & Exp. I & Exp. II \\
\hline \multicolumn{5}{|c|}{ Monilinia fructicola } \\
\hline CX27-1 & Pear & Shandong & $12.4 \mathrm{gh}$ & $11.2 \mathrm{gh}$ \\
\hline LS19-1 & Apple & Shandong & $10.0 \mathrm{~h}$ & $11.4 \mathrm{fgh}$ \\
\hline Mean & $\ldots$ & $\ldots$ & 11.2 (b) & 11.3 (a) \\
\hline \multicolumn{5}{|l|}{ M. fructigena } \\
\hline A2 & N/A & France & $12.4 \mathrm{gh}$ & $9.8 \mathrm{~h}$ \\
\hline CBS101499 & N/A & The Netherlands & $18.3 \mathrm{a}$ & $18.9 \mathrm{a}$ \\
\hline CBS101500 & N/A & The Netherlands & $16.2 \mathrm{abcd}$ & 15.9 abcd \\
\hline EP-5 & N/A & United Kingdom & $18.2 \mathrm{a}$ & $17 \mathrm{ab}$ \\
\hline EA-1 & N/A & United Kingdom & $16.8 \mathrm{abc}$ & 14.1 bcdefg \\
\hline Mean & $\ldots$ & $\ldots$ & 16.4 (a) & 15.1 (a) \\
\hline \multicolumn{5}{|c|}{ Monilia polystroma } \\
\hline CBS102686 & Apple & Japan & $17.7 \mathrm{ab}$ & 15.9 abcd \\
\hline LHX3 & Pear & Hebei & $17.3 \mathrm{ab}$ & 14.6 bcdef \\
\hline SDA2 & Apple & Shandong & $17.9 \mathrm{ab}$ & $16.8 \mathrm{abc}$ \\
\hline HML-3 & Plum & Heilongjiang & $17.5 \mathrm{ab}$ & 14.6 bcdef \\
\hline 2319 & Apple & Japan & $12.6 \mathrm{fg}$ & $10.8 \mathrm{gh}$ \\
\hline Mean & $\ldots$ & $\ldots$ & 16.6 (a) & 14.5 (a) \\
\hline \multicolumn{5}{|l|}{ M. yunnanensis } \\
\hline AST1 & Apple & Gansu & 14.8 cdef & 13.5 cdefg \\
\hline GP18 & Peach & Beijing & $14.2 \mathrm{defg}$ & 12.0 efgh \\
\hline LBD1 & Pear & Beijing & 15.8 bcde & 15.2 bcde \\
\hline YXS4 & Apple & Gansu & $13.4 \mathrm{efg}$ & $12.2 \mathrm{efgh}$ \\
\hline YN1-2-02 & Apple & Yunnan & $14.3 \mathrm{defg}$ & $13.3 \mathrm{defg}$ \\
\hline Mean & $\ldots$ & $\ldots$ & $14.5(\mathrm{ab})$ & 13.2 (a) \\
\hline
\end{tabular}

${ }^{y}$ For experiments (Exp.) I and II, numbers followed by different letters indicate that they were significantly different $(P \leq 0.05)$.

${ }^{\mathrm{z}} \mathrm{N} / \mathrm{A}=$ not available.

Table 2. Primers used in this study

\begin{tabular}{|c|c|c|c|}
\hline Primer $^{\mathbf{z}}$ & Primer sequences $\left(5^{\prime}-3^{\prime}\right)$ & Descriptions & References \\
\hline \multicolumn{4}{|l|}{ ITS } \\
\hline ITS1 & TCCGTAGGTGAACCTGCGG & To amplify and sequence the ITS & White and Bruns 1990 \\
\hline ITS4 & TCCTCCGCTTATTGATATGC & Same as ITS1 & White and Bruns 1990 \\
\hline \multicolumn{4}{|l|}{ Tubulin } \\
\hline Bt2a & GGTAACCAAATCGGTGCTGCTTTC & To amplify and sequence the $\beta$-tubulin & Glass and Donaldson 1995 \\
\hline Bt2b & ACCCTCAGTGTAGTGACCCTTGGC & Same as Bt2a & Glass and Donaldson 1995 \\
\hline \multicolumn{4}{|l|}{ Laccase 2} \\
\hline LacaF & GCATCTGCATCTGCTATTCCAGCT & To amplify and sequence laccase 2 & This study \\
\hline LacaR & CTTACCGCCACCAACGCAGTT & Same as LacaR & This study \\
\hline \multicolumn{4}{|c|}{ Species ID } \\
\hline $\mathrm{ClaF}$ & GGTAAGCGACATCGCATTCTCAC & Species-specific for Monilinia fructicola & This study \\
\hline ClaR & GAGGTAAATGTGGTAAATATGCAG & Same as $\mathrm{ClaF}$ & This study \\
\hline LlaF & ССАСТССТТСАААТАССАСТТ & Species-specific for Monilinia laxa & This study \\
\hline LlaR & GCTAGACTGGTACAAAAGGATGTTT & Same as LlaF & This study \\
\hline GPlaF & ССАСТТССААСАТСАСТС & Species-specific for Monilinia fructigena/Monilia polystroma & This study \\
\hline GlaR & GTAAAGGTGGCGTAATTTTGGATT & Species-specific for Monilinia fructigena & This study \\
\hline PlaR & CCCAGATTTCAAAAGCGGATTC & Species-specific for Monilia polystroma & This study \\
\hline GClaF & CCACTTCTTCGAATAACA & Species-specific for M. yunnanensis & This study \\
\hline GClaR & GGTTCCGTATTGAGTAACTTTA & Same as GClaF & This study \\
\hline
\end{tabular}

${ }^{\mathrm{z}}$ ITS $=$ internal transcribed spacer and Species ID = primers for species identification. 
GplaF/PlaR, GClaF/GClaR, and GplaF/GlaR were designed to distinguish Monilinia fructicola, M. laxa, Monilia polystroma, M. yunnanensis, and Monilinia fructigena, respectively (Table 2). Closely related species Botrytis cinerea, Sclerotinia sclerotiorum, and other fungi, including Colletotrichum sp., Alternaria sp. (218(2)), Valsa mali (Accc30052), Cladosporium fulvum, and Neofusicocum ribis (CBS118822), and oomycete Phytophthora cactorum, were used in experiments for testing primer specificity. PCR assays were performed in a $25-\mu \mathrm{l}$ volume containing $200 \mu \mathrm{M}$ each dNTP, $0.2 \mu \mathrm{M}$ each forward and reverse primer, $2.0 \mathrm{mM} \mathrm{MgCl}_{2}, 1.0 \mathrm{U}$ of $\mathrm{Taq}$ polymerase (CNS Bioservices Co. Ltd.), and 20 to $40 \mathrm{ng}$ of genomic DNA. PCR cycling parameters were $95^{\circ} \mathrm{C}$ for $3 \mathrm{~min}$; followed by 30 cycles of $95^{\circ} \mathrm{C}$ for $30 \mathrm{~s}, 60^{\circ} \mathrm{C}$ for $30 \mathrm{~s}$, and $72^{\circ} \mathrm{C}$ for $1.5 \mathrm{~min}$; and a final $72^{\circ} \mathrm{C}$ for $10 \mathrm{~min}$ in an Icycler Thermal Cycler. PCR products were separated by electrophoresis in $1.5 \%$ agarose gels as described above.

Phylogenetic analysis. The ITS regions were initially sequenced and analyzed; then, representative isolates were further selected according to the ITS sequences, host, geographic location of the isolates, and difference in colony characteristics for amplifying and sequencing the $T U B$ and $l c c 2$ genes (Table 1). Reference sequences of M. fructicola, M. laxa, M. fructigena, Monilia yunnanensis, M. polystroma, and M. mumecola were included (Table 1). Consensus sequences of the selected isolates were deposited in GenBank (Table 1). Sequence alignments were conducted in DNAMAN 7 (Lynnon Corporation) and alignments of each dataset were deposited in TreeBase (https://treebase.org/treebase-web/home.html). Maximumparsimony (MP) analyses were performed for each dataset of the ITS, $T U B, l c c 2$, and combined datasets of the three genes in PAUP $4.0 \mathrm{~b} 10$ (Swofford 2000). Gaps were treated as missing data. Trees were inferred using the heuristic searches with Tree-bisection-reconnection branch swapping and 100 random sequence additions. Branch stability was evaluated in a bootstrap analysis with 1,000 replicates, each with 100 replicates of random stepwise addition of taxa. A second phylogenetic analysis using the Markov Chain Monte Carlo (MCMC) algorithm was conducted to generate trees with Bayesian posterior probabilities in MrBayes v3.1.2 (Ronquist and Huelsenbeck 2003). Nucleotide substitution models were determined using Modeltest v 3.7 (Posada and Crandall 1998) for each gene region and included in the analysis. Two analyses of four MCMC chains were tested from random trees for at least 1 million generations and sampled every 100 generations until the average standard deviation of split frequencies was lower than 0.01 . The first $25 \%$ of trees were discarded as the burn-in phase of each analysis and posterior probabilities determined from the remaining trees. The phylogenetic trees were viewed using Treeview 1.6.6 (Page 1996). In addition, to determine whether the combined sequences could be used to construct phylogenetic analyses, statistical congruence was examined by applying

Table 4. Information of the sequence dataset and maximum-parsimony trees for each locus or combined sequences

\begin{tabular}{lcccc}
\hline & \multicolumn{4}{c}{ Locus $^{\mathbf{z}}$} \\
\cline { 2 - 5 } Information & ITS & TUB & lcc $\boldsymbol{~}$ & Combined \\
\hline Total alignable characters $(n)$ & 443 & 402 & 883 & 1,728 \\
Total variable characters $(n)$ & 406 & 304 & 599 & 1,320 \\
Parsimony-informative & 25 & 49 & 143 & 204 \\
$\quad$ characters $(n)$ & & & & \\
Most-parsimonious trees $(n)$ & 500 & 1 & 4 & 24 \\
Tree length & 46 & 131 & 370 & 530 \\
Consistency index & 0.8478 & 0.8931 & 0.8946 & 0.8943 \\
Homoplasy index & 0.1522 & 0.1069 & 0.1054 & 0.1057 \\
Retention index & 0.9646 & 0.9545 & 0.9673 & 0.9651 \\
Rescaled consistency index & 0.8179 & 0.8525 & 0.8653 & 0.8632 \\
\hline
\end{tabular}

${ }^{\mathrm{z}}$ ITS $=$ internal transcribed spacer, $T U B=\beta$-tubulin, $l c c 2=$ laccase, and Combined $=$ combined gene sequences.

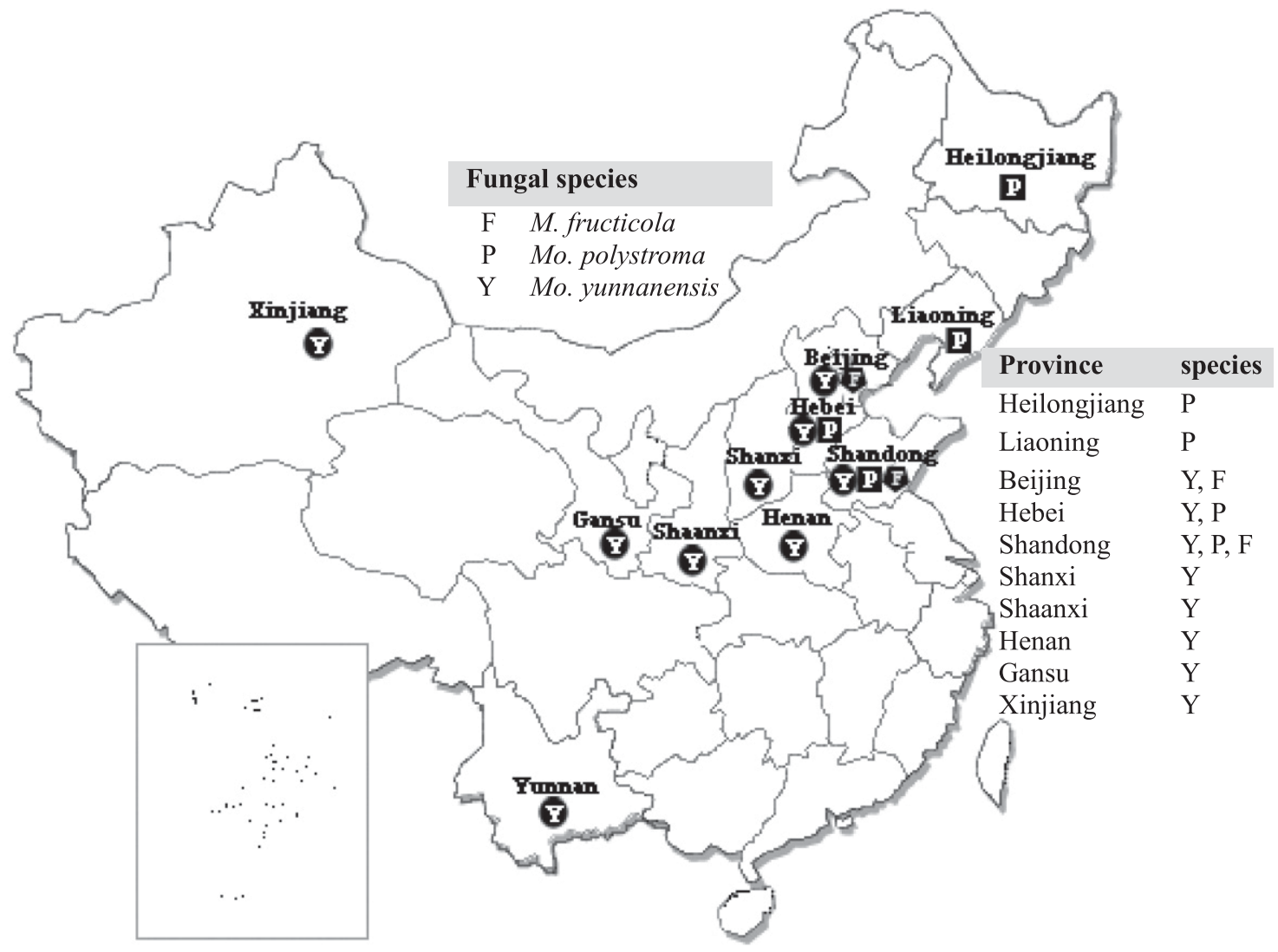

Fig. 1. Geographic distribution of brown rot pathogens on apple and pear in China. Species of Monilinia fructicola, Monilia polystroma, and M. yunnanensis are indicated as F, P, and $\mathrm{Y}$, respectively. 
a partition homogeneity test in PAUP 4.0b10 using 1,000 replicates and the heuristic standard search options (Swofford 2000).

Morphological characterization. The colony morphology of all 247 isolates collected in this study and that of the 11 reference isolates (Table 1) was determined on PDA. Colony expansion rate and conidial characteristics were assessed on representative isolates of $M$. yunnanensis and $M$. polystroma and reference isolates of Monilinia fructigena. To obtain uniform colonies for each of the isolates, a culture plug ( $5 \mathrm{~mm}$ in diameter) was cut from the edge of a 4-day-old colony and placed in the center of a petri dish $(9 \mathrm{~cm}$ in diameter) containing about $15 \mathrm{ml}$ of PDA. Three replicated dishes were used for each isolate. The dishes were kept at $22 \pm 2{ }^{\circ} \mathrm{C}$ with $12 \mathrm{~h}$ of near-UV light (wavelength $365.5 \mathrm{~nm}$ ) and $12 \mathrm{~h}$ of darkness (12/12-h regime) or in $24 \mathrm{~h}$ of darkness (24-h regime). Colony diameters were measured from two erected directions at 2 and 4 days after inoculation. After 6 days, critical characteristics such as the color of the culture and shape of the culture edge as described by Byrde and Willetts (1977), Lane (2002), and van Leeuwen et al. (2002) were determined for each isolate. After 37 days of incubation in darkness, the amount of stroma produced by each isolate was observed from the bottom side of each petri dish. After photographs were taken, the stroma areas in each dish were assessed by Image-Pro Plus (Media
Cybernetics Inc.) in comparison with the total area of each petri dish. The experiment was conducted twice.

To characterize conidia, they were harvested from inoculated apple fruit and from petri dish cultures with the mycelia scratching method described by Zhu et al. (2014). The length and width of 50 conidia/isolate were measured under a compound microscope at $\times 400$ (Olympus Model BX41TF).

Pathogenicity tests. Pathogenicity of representative isolates of M. fructicola, $M$. fructigena, Monilia yunnanensis, and M. polystroma was determined on apple fruit (Table 3). Mature apple ('Fuji') were purchased commercially and then washed in tap water, surface sterilized with $0.128 \% \mathrm{NaClO}$ for $15 \mathrm{~min}$, and rinsed three times with sterile distilled water. Each fruit was wounded with a nail $(2 \mathrm{~mm}$ in diameter and $3 \mathrm{~mm}$ in depth) before placing a mycelial plug ( $5 \mathrm{~mm}$ in diameter), cut from the edge of a 6-day-old colony, on the wound. Fruit inoculated with plain PDA plugs were used as controls. Inoculated fruit were placed on two layers of moist paper towels on a wire rack in a plastic container at room temperature $\left(24.5 \pm 2{ }^{\circ} \mathrm{C}\right)$. Two fruit were used as a replicate and three replicates were used for each tested isolate. Symptoms were observed 2 days after inoculation, lesion diameters were measured 2 and 4 days after inoculation, and lesion expansion rate (millimeters per day) was calculated

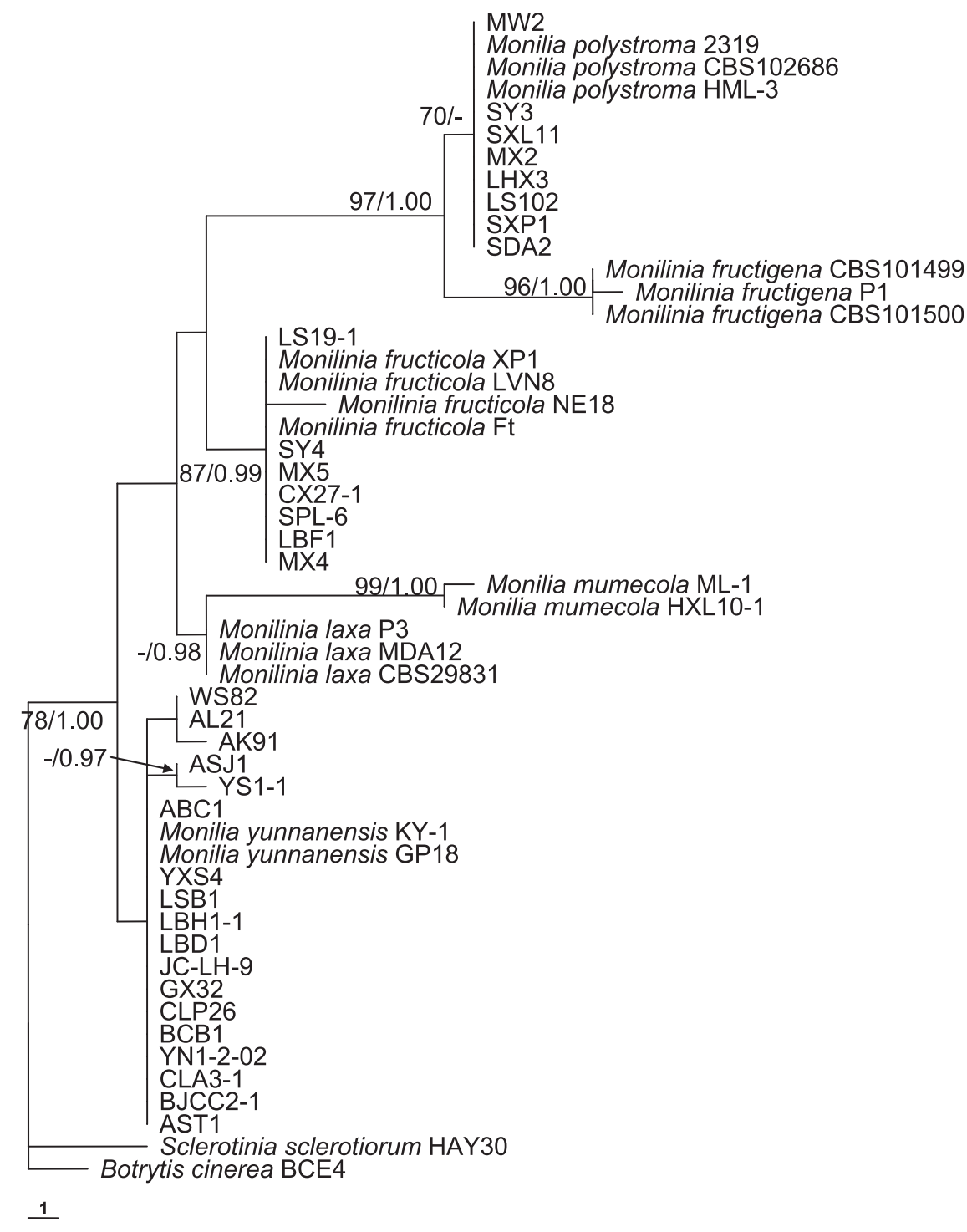

Fig. 2. Phylogram (1 of 500) of the Monilinia spp. and Monilia species complex based on maximum-parsimony analysis with internal transcribed spacer (ITS) sequences. Tree length $=46$, consistency index $=0.8478$, retention index $=0.9646$, rescaled consistency index $=0.8179$, and homoplasy index $=0.2121$. Botrytis cinerea and Sclerotinia sclerotiorum were used as outgroups. Bootstrap support values (1,000 replicates) above $70 \%$ and posterior probabilities above 0.95 for Bayesian analysis were shown at the branches. Species are followed by strain numbers. 
based on the two measurements. The experiment was conducted twice.

Statistical analysis. Mean growth rate, area of stroma, conidial dimensions, and lesion expansion rate were analyzed for each isolate. Data from M. yunnanensis, M. polystroma, and Monilinia fructigena were analyzed with SAS 8.0 (SAS Institute) using the general linear models (Proc GLM) at $P \leq 0.05$. Means were compared using Tukey's least significant difference test when effects were found to be statistically significant.

\section{Results}

Isolate collection and colony morphology. In all, 247 isolates were obtained from apple and pear fruit with typical brown rot symptoms, originating from 51 orchards in 10 provinces (or cities), including Beijing, Shandong, Hebei, Henan, Gansu, Shaanxi, Shanxi, Yunnan, Xinjiang, and Heilongjiang (Table 1; Fig. 1). Colony characteristics were separated into three groups with respective reference isolates of $M$. fructicola (Ft, CBS167.24), M. fructigena (CBS101499, P1)/Monilia yunnanensis (GP18), and M. polystroma (CBS102686, 2319). Isolates in group I developed light-grayish to grayish zonate colonies with entire margins and abundant sporulation on the surface, similar to Monilinia fructicola. Isolates in group II had white to grayish colonies with entire margins but with little or no stroma, similar to M. fructigena and Monilia yunnanensis. Isolates in group III had white to grayish colonies with entire margins and abundant stroma, similar to M. polystroma (Supplementary Fig. S1).

Phylogenetic analysis. The ITS regions of 150 of the 247 isolates, which covered all the hosts, sampled regions, and colony groups, were amplified, sequenced, and analyzed with the reference isolates. Thirty-one representative isolates were further selected for sequencing $T U B$ and $l c c 2$ genes and used in phylogenetic analysis with the reference species (Table 1). The obtained sequences were approximately $537 \mathrm{bp}$ for the ITS region, $450 \mathrm{bp}$ for the $T U B$ gene, and $850 \mathrm{bp}$ for the $l c c 2$ gene. The aligned sequences of each dataset of ITS (57 taxa, 421 characters) (Supplementary Fig. S2), TUB (58 taxa, 402 characters), and $l c c 2$ (54 taxa, 762 characters) gene regions were deposited in TreeBase. The combined datasets including ITS, TUB, and $l c c 2$ were also analyzed through the partition homogeneity test before catenation, and no significant conflicts $(P \geq 0.05)$ were found among these datasets. The statistical data resulting from the parsimony analysis of individual trees are summarized in Table 4. For Bayesian analysis, model test analysis recommended appropriate models as follows: a TrNef + I model (Lset Base $=$ equal, Nst $=6$, Rmat $=[1.0000$ $2.10721 .00001 .00007 .6511]$, Rates $=$ equal, Pinvar $=0.8027)$ for the ITS region, an HKY + I model (Lset Base $=[0.24840 .2550$

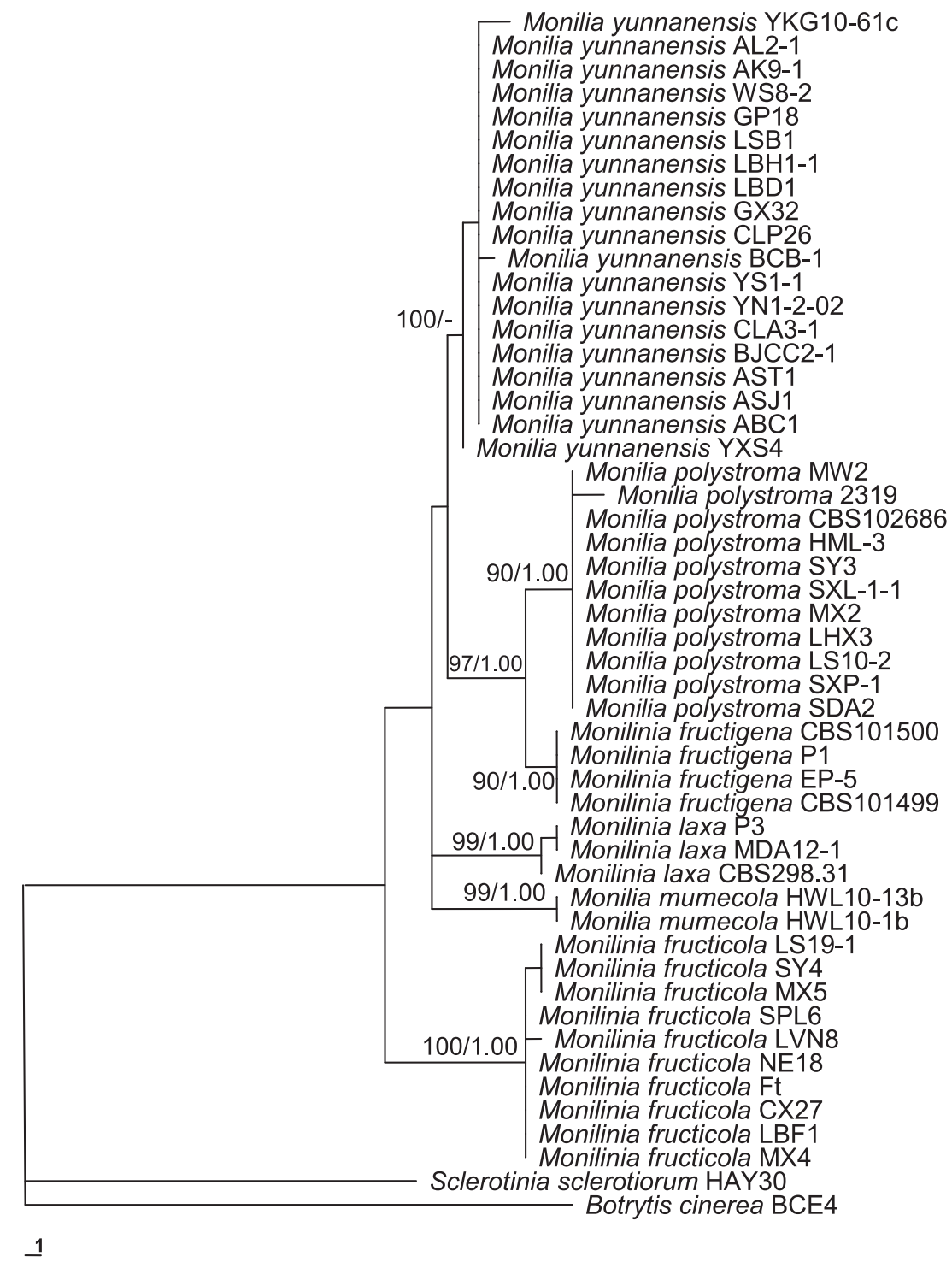

Fig. 3. Phylograms of the Monilinia spp. and Monilia complex based on maximum-parsimony analysis with the $\beta$-tubulin gene. Tree length $=131$, consistency index $=0.8931$, retention index $=0.9545$, rescaled consistency index $=0.8525$, and homoplasy index $=0.1892$. Botrytis cinerea and Sclerotinia sclerotiorum were used as outgroups. Bootstrap support values (1,000 replicates) above $70 \%$ and posterior probabilities above 0.95 for Bayesian analysis were shown at the branches. Species are followed by strain numbers. 
$0.2066], \mathrm{Nst}=2$, TRatio $=2.9282$, Rates $=$ equal, Pinvar $=0.6159)$ for the TUB gene region, a TrN + I model (Lset Base $=[0.2593$

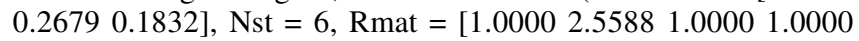
4.5592], Rates $=$ equal, Pinvar $=0.4261$ ) for the $l c c 2$ gene region, and a $\operatorname{TrN}+$ I model (Lset Base $=\left[\begin{array}{ll}0.2521 & 0.25650 .2000\end{array}\right], \mathrm{Nst}=6$,

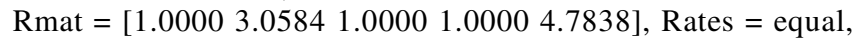
Pinvar $=0.5820$ ) for combined sequences of the three gene regions. The topologies of trees resulting from each gene region and the combined gene regions were basically similar in the MP and Bayesian inference.

Four phylogenetic trees were reconstructed from MP analysis (Figs. 2, 3, 4, and 5) and the tested isolates resided in three groups (Figs. 2, 3, 4, and 5) with reference sequences of Monilinia fructicola, Monilia yunnanensis, and M. polystroma, respectively. All the isolates in morphology group I were clustered together with reference isolates of Monilinia fructicola. All the isolates in morphology group II with colony characteristics of $M$. fructigena or Monilia yunnanensis were clustered together with M. yunnanensis but not Monilinia fructigena. However, isolates in morphology group III that showed colony characteristics similar to those of Monilia polystroma were divided into two clusters. One was grouped with $M$. yunnanensis and the others grouped with $M$. polystroma. Phylogenetic analysis also showed that M. polystroma, M. yunnanensis, and Monilinia fructigena were closely related (Figs. 2, 3, 4, and 5) and Monilia polystroma was more closely related to Monilinia fructigena than Monilia yunnanensis.
Morphological characteristics of M. yunnanensis, M. polystroma, and Monilinia fructigena. In the 12/12-h regime, mean growth rates were $12.43 \mathrm{~mm} \mathrm{day}{ }^{-1}$ for Monilia yunnanensis, $12.41 \mathrm{~mm} \mathrm{day}^{-1}$ for M. polystroma, and $10 \mathrm{~mm} \mathrm{day}^{-1}$ for Monilinia fructigena. In the 24-h regime, mean growth rates were 12.14 , 10.98, and $9.75 \mathrm{~mm} \mathrm{day}{ }^{-1}$, respectively. Among these species, Monilia yunnanensis grew significantly faster than Monilinia fructigena $(P<0.05)$ in both light regimes (Table 5), Monilia polystroma grew significantly faster than Monilinia fructigena in the 12/12-h regime but not in the 24 -h regime $(P<0.05)$ (Table 5), and Monilia yunnanensis and $M$. polystroma had similar growth rates at both light regimes $(P<0.05)$ (Table 5).

When conidia produced in vitro and in vivo were compared, the length and width of conidia produced by Monilinia fructigena were significantly larger than those of Monilia yunnanensis and M. polystroma $(P<0.05$; Table 5). However, consistent differences in the ratio of length and width of conidia among these three species were not observed. The stroma was commonly observed in cultures of M. polystroma and M. yunnanensis after 7 to 10 days of incubation and the amount of stroma increased with culture age but little or no stroma was observed for isolates of Monilinia fructigena after 37 days of incubation. The amount of stroma formed in petri dishes ranged from 0.66 to $7.02 \mathrm{~cm}^{2}$ with Monilia yunnanensis, 5.76 to $15.74 \mathrm{~cm}^{2}$ with $M$. polystroma, and 0 to $2.71 \mathrm{~cm}^{2}$ with Monilinia fructigena (Table 5). Although isolates of Monilia polystroma produced significantly more stroma than those of Monilinia fructigena

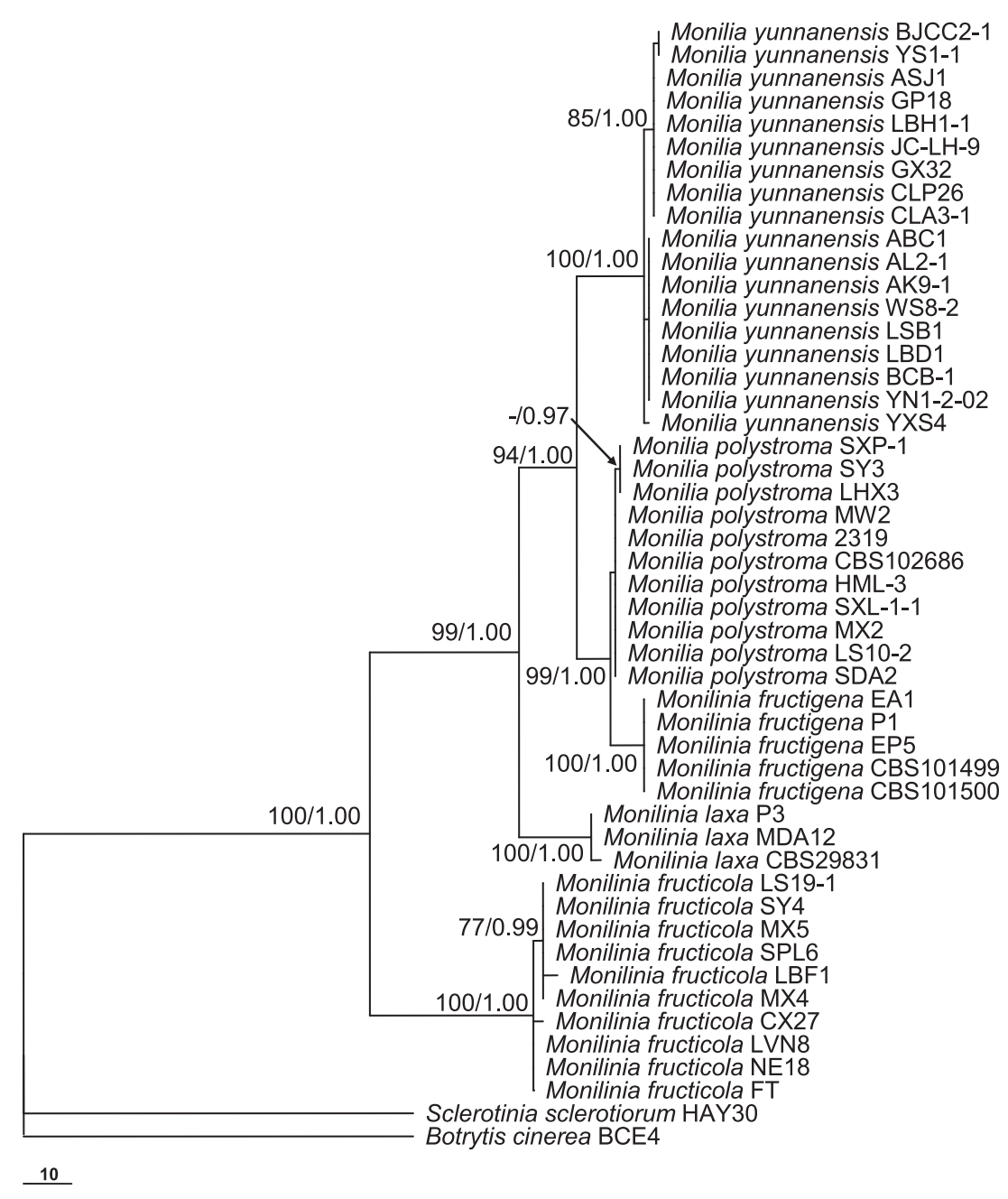

Fig. 4. Phylogram (one of four) of the Monilinia spp. and Monilia complex based on maximum-parsimony analysis with the laccase gene. Tree length $=370$, consistency index $=$ 0.8946 , retention index $=0.9673$, rescaled consistency index $=0.8653$, and homoplasy index $=0.1054$. Botrytis cinerea and Sclerotinia sclerotiorum were used as outgroups Bootstrap support values (1,000 replicates) above $70 \%$ and posterior probabilities above 0.95 for Bayesian analysis were shown at the branches. Species are followed by strain numbers. 
and Monilia yunnanensis in general $(P<0.05)$, variation in the ability to form stroma within each species was obvious and the ranges of the amount of stroma produced by M. yunnanensis overlapped with those of Monilinia fructigena and Monilia polystroma (Table 5). Therefore, within a species, Monilinia fructigena, Monilia polystroma, and M. yunnanensis do not show consistent differences in morphological characteristics, including colony morphology, colony expansion rate, conidial characteristics, and the amount of stroma produced in culture.

Discrimination of Monilinia spp. from other related species by conventional PCR. Sequence variation in $T U B$ and $l c c 2$ genes was found among the six closely related species of brown rot pathogens. For the $T U B$ gene region, a total of $9 \mathrm{bp}$ differences were found between M. yunnanensis and Monilinia fructigena, and $9 \mathrm{bp}$ differences were observed between Monilia yunnanensis and M. polystroma (Supplementary Fig. S3). However, just 4 bp differences were observed between M. polystroma and Monilinia fructigena. For the $l c c 2$ gene region, 31 bp differences were found between Monilia yunnanensis and Monilinia fructigena, $25 \mathrm{bp}$ differences were observed between Monilia yunnanensis and M. polystroma, but just 8 bp differences were observed between $M$. polystroma and Monilinia fructigena (Supplementary Fig. S4). Subsequently, species-specific primers were designed based on the differences observed in the $l c c 2$ gene (Table 2), and the expected PCR products of 597, 731, 387, and 152 bp were produced in Monilia yunnanensis, M. polystroma, Monilinia fructicola and M. laxa, respectively (Fig. 6), whereas no product was produced from $M$. fructigena, Monilia mumecola, or reference isolates of other species. The PCR method using these primers was then implemented to identify the remaining 97 isolates collected from pome fruit, and PCR products were produced from all the isolates examined. Among the 97 isolates, 68 were identified as M. yunnanensis, which were amplified only by the primer pair $\mathrm{GClaF} / \mathrm{GClaR}$ with a product of $597 \mathrm{bp}$; the other 29 isolates were identified as $M$. polystroma, which were amplified only by the primer pair GPlaF/PlaR with a product of $731 \mathrm{bp}$.

Monilinia spp. on cultivated apple and pear in China. Based on the morphological characteristics, sequence, and phylogenetic analysis of the ITS, TUB, and $l c c 2$ gene regions, and the molecular identification, 191 of the 247 isolates were M. yunnanensis, 49 were M. polystroma, and 7 were Monilinia fructicola. All three species were detected in Shandong province (Fig. 1). Both Monilia yunnanensis and M. polystroma were detected in Hebei province (Fig. 1). M. yunnanensis and Monilinia fructicola were found in Beijing. A single species (Monilia polystroma) was detected in the northeast, including Heilongjaing and Liaoning provinces (Fig. 1), whereas a different single species (M. yunnanensis) was found in the west, including Xinjiang, Gansu, Shaanxi, Shanxi, Yunnan, and Henan provinces (Fig. 1)

Pathogenicity tests. All apple fruit inoculated with tested isolates produced typical symptoms of brown rot, whereas no decay was developed on the controls. In experiment $\mathrm{I}$, the average expansion rate of lesions caused by $M$. polystroma, Monilinia fructigena, and

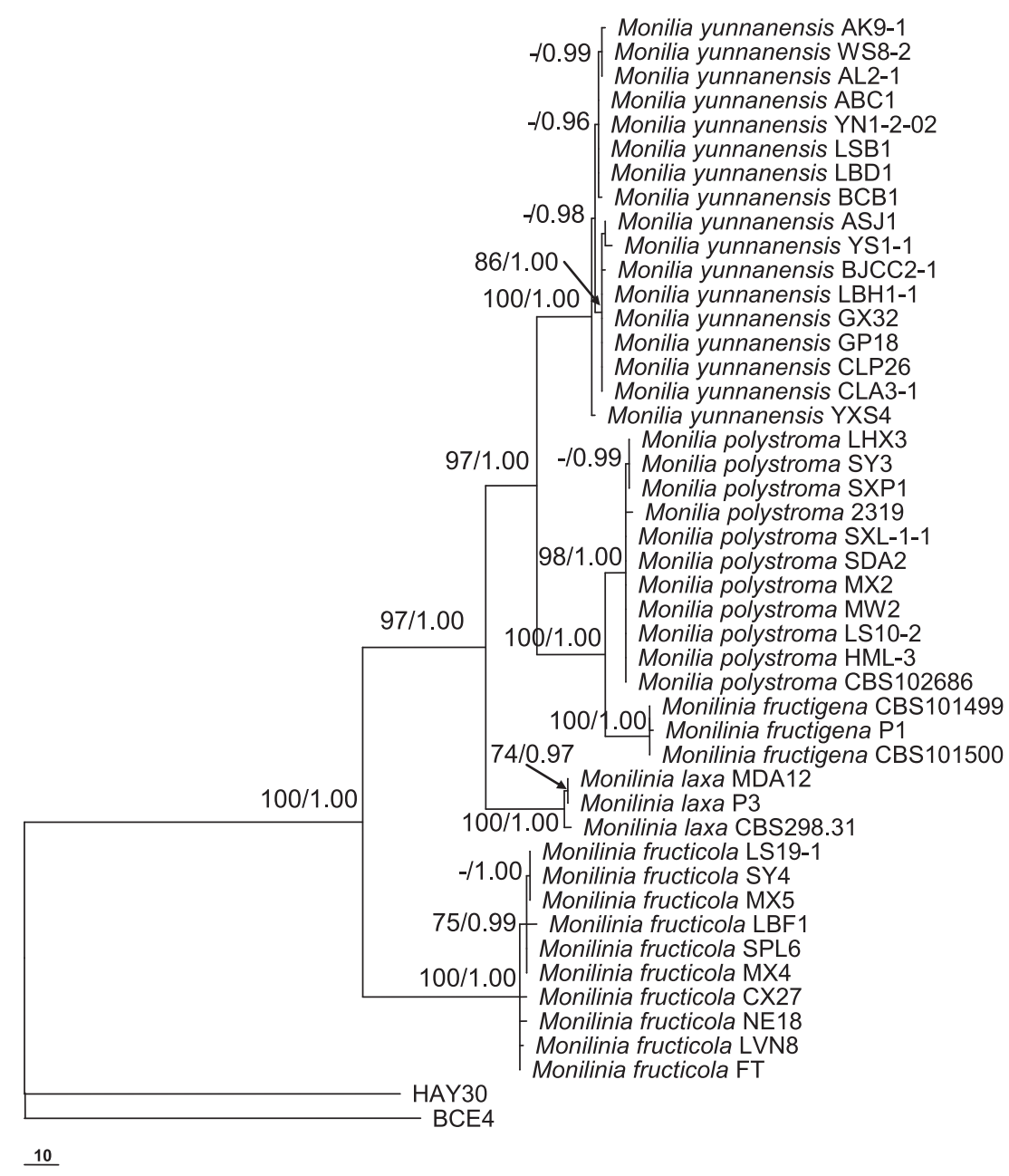

Fig. 5. Phylogram (1 of 24) of the Monilinia and Monilia species complex based on maximum-parsimony analysis with a combination of internal transcribed spacer, $\beta$-tubulin, and laccase gene sequences. Tree length $=530$, consistency index $=0.8943$, retention index $=0.9651$, rescaled consistency index $=0.8632$, and homoplasy index $=0.1867$. Botrytis cinerea and Sclerotinia sclerotiorum were used as outgroups. Bootstrap support values ( 1,000 replicates) above $70 \%$ and posterior probabilities above 0.95 for Bayesian analysis were shown at the branches. Species are followed by strain numbers. 
Monilia yunnanensis was 16.6, 16.4, and $14.5 \mathrm{~mm} \mathrm{day}^{-1}$, respectively, which were significantly larger than that $\left(11.2 \mathrm{~mm} \mathrm{day}{ }^{-1}\right)$ caused by Monilinia fructicola $(P<0.05)$ (Table 3$)$. However, this difference was not significant in experiment II $(P<0.05)$ (Table 3$)$.

\section{Discussion}

This study represents the first report of the identification to species of an extensive collection of brown rot fungi from apple and pear fruit in China. Based on a combination of morphological characterization, multigene sequences, and a conventional PCR method, we found that three species were present. Among them, Monilia yunnanensis was the most prevalent (77\%), followed by $M$. polystroma (20\%) and Monilinia fructicola (3\%). Pathogenicity tests showed that all three species caused fruit decay on wounded apple fruit. Moreover, a set of species-specific primers was successfully developed in this study for identifying M. fructicola, Monilia polystroma, M. yunnanensis, and Monilinia laxa.

Among the three brown rot pathogens discovered in this study, Monilia polystroma is a species that was recently differentiated from Monilinia fructigena based on stroma formation, growth rate, conidia size, and ITS sequence (van Leeuwen et al. 2002), and Monilia yunnanensis is a new species recently reported on stone fruit and is differentiated from Monilinia fructigena based on spore size, colony morphology, lesion growth rate, and sporulation (Hu et al. 2011; Zhu et al. 2011). Previously, Monilia polystroma has been found on plum in Heilongjiang (Zhu and Guo 2010) and M. yunnanensis has been found on peach in Yunnan (Hu et al. 2011) but this is the first time that they have been found on pome fruit. Previously, Monilinia fructigena and M. laxa were reported on cultivated stone and pome fruit by Wang et al. (1998); however, neither were found on pome fruit in this study or in other extensive surveys conducted recently on stone fruit in China (Hu et al. 2011; Yin et al. 2015; Zhu et al. 2011). Because no preserved cultures from Wang et al. (1998) are available, reidentification is not possible. Considering that Monilia yunnanensis and M. polystroma are new species that recently differentiated from Monilinia fructigena and given the prevalence of Monilia yunnanensis and M. polystroma in this study, the Monilinia fructigena that Wang et al. (1998) reported most likely was Monilia yunnanensis or M. polystroma, depending on the sampling location of the isolates, because these two species had unique geographic distributions, as indicated in data from this study.

The results from the current investigation showed that, although M. yunnanensis, M. polystroma, and Monilinia fructigena can be differentiated from each other based on the sequence differences in ITS, $T U B$, and $l c c 2$ gene regions, they do not show distinct differences in their morphological characteristics, including colony morphology, colony expansion rate, conidial characteristics, and the amount of stroma produced (Hu et al. 2011; van Leeuwen et al. 2002). Phylogenetic analysis based on multigenes suggested that these three species are closely related, and Monilia yunnanensis is more distantly related to the others. The three species also showed differences in geographic distribution. Thus, they are more like phylogenetic species in the process of speciation.

Previously, Monilinia fructicola was detected as the major species on stone fruit in China (Hu et al. 2011; Zhu et al. 2011) but it was detected on only a few samples of pome fruit, even in Shandong, where $M$. fructicola is widely distributed and peach and nectarine are grown in orchards adjacent to apple. This suggests that $M$. fructicola preferentially attacks stone fruit even though its virulence on wounded apple is not significantly different from that of M. fructigena, Monilia yunnanensis, and M. polystroma. Similarly, like Monilinia fructigena, Monilia yunnanensis and $M$. polystroma tend to attack pome fruit in situ (EPPO/CABI 1997).

In this study, a set of species-specific primers based on differences in the $l c c 2$ gene was designed and a conventional PCR method was established that successfully differentiated Monilinia fructicola, Monilia polystroma, M. yunnanensis, and Monilinia laxa from other Monilinia spp. The primer designed for M. fructigena failed to differentiate it from Monilia polystroma. Similarly, the universal PCR method developed by Ioos and Frey (2000) based on ITS sequence differences did not differentiate Monilinia fructicola and the other brown rot fungi (Fan et al. 2007; Hu et al. 2011; Zhu et al. 2011). Previously, a real-time PCR method could distinguish $M$. fructicola from M. laxa, M. fructigena, and Monilia polystroma (van Brouwershaven et al. 2010) when M. yunnanensis was not included in the test. Therefore,

Table 5. Biological characteristics of Monilinia fructigena (MF), Monilia polystroma (MP), and M. yunnanensis (MY)

\begin{tabular}{|c|c|c|c|}
\hline \multirow[b]{2}{*}{ Characteristics $^{\mathrm{v}}$} & \multicolumn{3}{|c|}{ Species $^{\mathbf{u}}$} \\
\hline & MF (6) & MP (7) & MY (6) \\
\hline \multicolumn{4}{|l|}{$\overline{\text { Growth rate }\left(\mathrm{mm} \mathrm{day}^{-1}\right)^{\mathrm{w}}}$} \\
\hline \multicolumn{4}{|l|}{ 12/12-h regime ${ }^{\mathrm{x}}$} \\
\hline Mean \pm SD & $10.00 \pm 1.4 \mathrm{~b}$ & $12.41 \pm 2.8 \mathrm{a}$ & $12.43 \pm 0.3 \mathrm{a}$ \\
\hline Range & 7.89-11.39 & $9.11-16.50$ & $12.0-12.86$ \\
\hline \multicolumn{4}{|l|}{ 24-h regime ${ }^{\mathrm{y}}$} \\
\hline Mean \pm SD & $9.75 \pm 1.93 b$ & $10.98 \pm 0.72 \mathrm{ab}$ & $12.14 \pm 0.93 \mathrm{a}$ \\
\hline Range & $7.31-12.33$ & $10.17-12.17$ & $10.70-13.28$ \\
\hline \multicolumn{4}{|l|}{ Conidial size $(\mu \mathrm{m})^{\mathrm{z}}$} \\
\hline $\mathrm{L} \times \mathrm{W}($ mean $\pm \mathrm{SD})$ & $18.52 \pm 2.68 \times 12.75 \pm 1.87 \mathrm{a}$ & $15.33 \pm 1.56 \times 11.20 \pm 1.28 \mathrm{~b}$ & $15.18 \pm 0.74 \times 11.38 \pm 0.85 b$ \\
\hline Range & $16.90-21.62 \times 11.00-14.71$ & $13.65-17.89 \times 9.6-13.18$ & $13.94-15.91 \times 10.43-12.18$ \\
\hline $\mathrm{L} / \mathrm{W}($ mean $\pm \mathrm{SD})$ & $1.46 \pm 0.10 \mathrm{a}$ & $1.37 \pm 0.03 \mathrm{ab}$ & $1.34 \pm 0.05 \mathrm{~b}$ \\
\hline Range & $1.35-1.55$ & $1.34-1.42$ & $1.28-1.41$ \\
\hline \multicolumn{4}{|l|}{ From mycelia scratching } \\
\hline $\mathrm{L} \times \mathrm{W}($ mean $\pm \mathrm{SD})$ & $15.58 \pm 2.44 \mathrm{a} \times 11.41 \pm 1.62 \mathrm{a}$ & $14.61 \pm 2.30 \mathrm{ab} \times 10.84 \pm 1.65 \mathrm{~b}$ & $13.02 \pm 1.75 b \times 9.85 \pm 1.55 b$ \\
\hline Range & $10.28-22.44 \times 8.36-15.27$ & $7.51-18.97 \times 7.10-13.78$ & $8.92-15.30 \times 7.84-14.94$ \\
\hline $\mathrm{L} / \mathrm{W}($ mean $\pm \mathrm{SD})$ & $1.37 \pm 0.11 \mathrm{a}$ & $1.35 \pm 0.15 \mathrm{a}$ & $1.33 \pm 0.14 \mathrm{a}$ \\
\hline Range & $1.17-1.50$ & $1.03-1.53$ & $1.09-1.46$ \\
\hline \multicolumn{4}{|l|}{ Stromata } \\
\hline Mean $\pm \mathrm{SD}\left(\mathrm{cm}^{2}\right)$ & $1.20 \pm 1.09 \mathrm{~b}$ & $10.97 \pm 2.85 \mathrm{a}$ & $3.57 \pm 3.31 \mathrm{~b}$ \\
\hline Range & $0-2.71$ & $5.76-15.74$ & $0.66-7.02$ \\
\hline
\end{tabular}

u Numbers in parenthesis after species name abbreviations indicate the number of isolates tested. Numbers followed by different letters are significantly different ( $t$ test) at $P=0.05$.

v $\mathrm{SD}=$ standard deviation, Range $=$ minimum to maximum, $\mathrm{L}=$ length, and $\mathrm{W}=$ width.

${ }^{\mathrm{w}}$ Colony growth rate.

$\mathrm{x}$ Replicated dishes kept in $12 \mathrm{~h}$ of light and $12 \mathrm{~h}$ of darkness.

y Replicated dishes kept in $24 \mathrm{~h}$ of darkness.

z Grown on apple. 
sequence differences on other gene regions or a more sensitive method such as real-time PCR should be investigated.

In summary, brown rots on cultivated apple and pear fruit in China are caused by three species: Monilinia fructicola, Monilia polystroma, and M. yunnanensis, with M. yunnanensis being dominant. M. yunnanensis, M. polystroma, and Monilinia fructigena are closely related, with distinct sequence difference in several genes, but do not show consistent differences in morphological characteristics. Thus, they are more like phylogenetic species in the process of speciation. A set of species-specific primers and a conventional PCR method were successfully developed in this research for differentiating M. fructicola, Monilia polystroma, M. yunnanensis, and Monilinia laxa from other Monilinia spp. Results of this study provide useful inputs for species identification of brown rot pathogens.

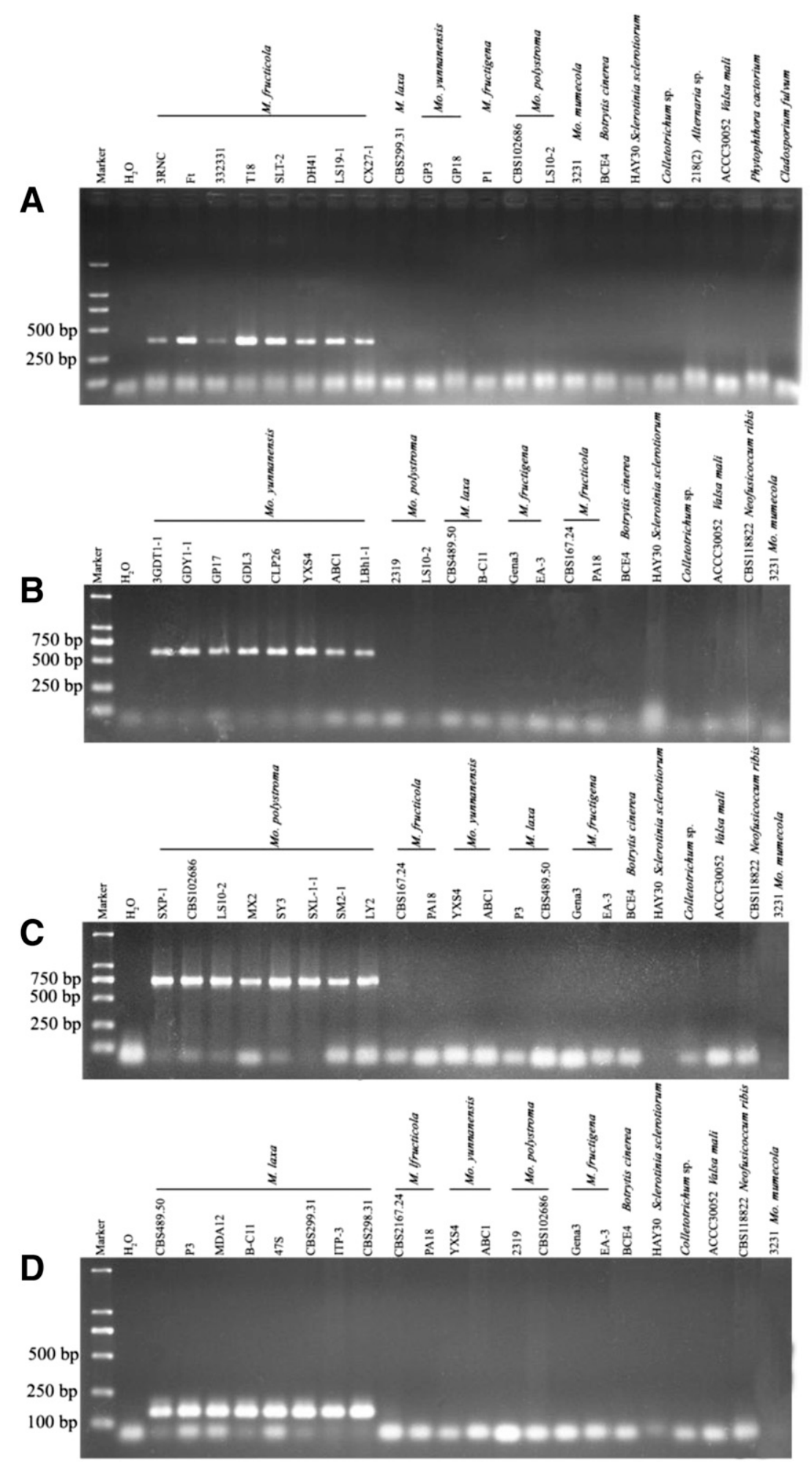

Fig. 6. Electrophoresis of polymerase chain reaction (PCR) products obtained using species-specific primers that were designed in this study. A, ClaF/ClaR for Monilinia fructicola. PCR product was about $450 \mathrm{bp}$. B, GClaF/GClaR for Monilia yunnanensis. PCR product was about $600 \mathrm{bp}$. C, GPlaF/PlaR for M. polystroma. PCR product was about 750 bp. D, LlaF/LlaR for Monilinia laxa. PCR product was about $150 \mathrm{bp}$. 


\section{Acknowledgments}

This work was supported by the National Natural Science Foundation of China (31201469) and the Earmarked Fund for Modern Agro-industry Technology Research System (CARS-28). We thank H.-H. Zheng, Y.-L. Fang, and M. Li for sample collection, conducting some species identification, or pathogenicity tests in this study; and G.-Y. Sun of Northwest A\&F University and J.-P. Li of the Institute of Plant Protection of the Academy of Gansu Agricultural Science for their help with sample collection.

\section{Literature Cited}

Berrie, A. M., and Holb, I. 2014. Brown rot diseases. Pages 43-45 in: Compendium of Apple and Pear Diseases and Pests, 2nd ed. T. B. Sutton, H. S. Aldwinckle, A. M. Agnello, and J. F. Walgenbach, eds. American Phytopathological Society, St. Paul, MN.

Bosshard, E., Hilber-Bodmer, M., Schaerer, H. J., Buenter, M., and Duffy, B. 2006. First report of the quarantine brown rot pathogen Monilinia fructicola on imported stone fruits in Switzerland. Plant Dis. 90:1554.

Byrde, R. J. W., and Willetts, H. J. 1977. The Brown Rot Fungi of Fruit: Their Biology and Control. Pergamon Press, New York.

Cote, M. J., Prud'Homme, M., Meldrum, A. J., and Tardif, M. C. 2004. Variations in sequence and occurrence of SSU rDNA group I introns in Monilinia fructicola isolates. Mycologia 96:240-248.

De Cal, A., Gell, I., Usall, J., Vinas, I., and Melgarejo, P. 2009. First report of brown rot caused by Monilinia fructicola in peach orchards in Ebro Valley, Spain. Plant Dis. 93:763.

Di Francesco, A., Fruk, M., Martini, C., Jemric, T., and Mari, M. 2015. First report of Asiatic brown rot (Monilinia polystroma) on apple in Croatia. Plant Dis. 99:1181.

Duchoslavová, J., Siruckova, I., Zapletalova, E., Navratil, M., and Safarova, D. 2007. First report of brown rot caused by Monilinia fructicola on various stone and pome fruits in the Czech Republic. Plant Dis. 91:907.

EPPO/CABI. 1997. Quarantine Pests for Europe, 2nd ed. CAB International, Wallingford, UK.

Fan, J. Y., Guo, L. Y., Xu, J. P., Luo, Y., and Michailides, T. J. 2010. Genetic diversity of populations of Monilinia fructicola (Fungi, Ascomycota, Helotiales) from China. J. Eukaryot. Microbiol. 57:206-212.

Fan, J. Y., Luo, Y., Michailides, T. J., and Guo, L. Y. 2014. Simultaneous quantification of alleles E198A and H6Y in the $\beta$-tubulin gene conferring benzimidazole resistance in Monilinia fructicola using a duplex real-time (TaqMan) PCR. Pest Manage. Sci. 70:245-251.

Fan, J. Y., Zhu, X. Q., Guo, L. Y., and Luo, Y. 2007. Comparison of three molecular identification methods for Monilinia species on stone and pome fruits. Acta Phytophylac. Sin. 34:289-295.

Gell, I., Cubero, J., and Melgarejo, P. 2007. Two different PCR approaches for universal diagnosis of brown rot and identification of Monilinia spp. in stone fruit trees. J. Appl. Microbiol. 103:2629-2637.

Glass, N. L., and Donaldson, G. C. 1995. Development of primer sets designed for use with the PCR to amplify conserved genes from filamentous ascomycetes. Appl. Environ. Microbiol. 61:1323-1330.

Grabke, A., Hu, M. J., Luo, C. X., Bryson, P. K., and Schnabel, G. 2011. First report of brown rot of apple caused by Monilinia fructicola in Germany. Plant Dis. 95:772.

Hall, T. 2011. BioEdit: A user-friendly biological sequence alignment editor and analysis program for Windows 95/98/NT. Nucleic Acids Symp. Ser. 41:95-98.

Harada, Y., Nakao, S., Sasaki, M., Sasaki, Y., Ichihashi, Y., and Sano, T. 2004. Monilia mumecola, a new brown rot fungus on Prunus mume in Japan. J. Gen. Plant Pathol. 70:297-307.

Hilber-Bodmer, M., Bunter, M., and Patocchi, A. 2010. First report of brown rot caused by Monilinia fructicola on apricot in a Swiss orchard. Plant Dis. 94:643.

Hily, J., Singer, S. D., Villani, S. M., and Cox, K. D. 2011. Characterization of the cytochrome b (cytb) gene from Monilinia species causing brown rot of stone and pome fruit and its significance in the development of QoI resistance. Pest Manage. Sci. 67:385-396.

Hirschhäuser, S., and Fröhlich, J. 2007. Multiplex PCR for species discrimination of Sclerotiniaceae by novel laccase introns. Int. J. Food Microbiol. 118:151-157.

Hu, M., Cox, K. D., Schnabel, G., and Luo, C. X. 2011. Monilinia species causing brown rot of peach in china. PLoS One 6:e24990.

Ioos, R., and Frey, P. 2000. Genomic variation within Monilinia laxa, $M$. fructigena and $M$. fructicola, and application to Species Identification by PCR. Eur. J. Plant Pathol. 106:373-378.

Lane, C. R. 2002. A synoptic key for differentiation of Monilinia fructicola, $M$. fructigena and M. laxa, based on examination of cultural characters. Bull. OEPP/EPPO Bull. 32:489-493.
Ma, Z., Luo, Y., and Michailides, T. J. 2003. Nested PCR assays for detection of Monilinia fructicola in stonefruit orchards and Botryosphaeria dothidea from pistachios in California. J. Phytopathol. 151:312-322.

Miessner, S., and Stammler, G. 2010. Monilinia laxa, M. fructigena and M. fructicola: Risk estimation of resistance to QoI fungicides and identification of species with cytochrome b gene sequences. J. Plant Dis. Prot. 117:162-167.

Munda, A. 2015. First report of brown rot on peach caused by Monilia polystroma in Slovenia. Plant Dis. 99:1281.

Munda, A., and Marn, M. V. 2010. First report of brown rot caused by Monilinia fructicola affecting peach orchards in Slovenia. Plant Dis. 94:1166.

OEPP/EPPO. 2002. First report of Monilinia fructicola in France. EPPO Reporting Service 2002/03.

Page, R. 1996. TREEVIEW: An application to display phylogenetic trees on personal computers. Comput. Appl. Biosci. 12:357-358.

Pellegrino, C., Gullino, M. L., Garibaldi, A., and Spadaro, D. 2009. First report of brown rot of stone fruit caused by Monilinia fructicola in Italy. Plant Dis. 93 668

Peter, K. A., Gaskins, V. L., Lehman, B., and Jurick, W. M. 2015. First report of brown rot on apple fruit caused by Monilinia fructicola in Pennsylvania. Plant Dis. 99:1179.

Petróczy, M., and Palkovics, L. 2006. First report of brown rot caused by Monilinia fructicola on imported peach in Hungary. Plant Dis. 90:375.

Petróczy, M., and Palkovics, L. 2009. First report of Monilia polystroma on apple in Hungary. Eur. J. Plant Pathol. 125:343-347.

Petróczy, M., Szigethy, A., and Palkovics, L. 2012. Monilinia species in Hungary: Morphology, culture characteristics, and molecular analysis. Trees (Berl.) 26: 153-164.

Poniatowska, A., Michalecka, M., and Bielenin, A. 2013. Characteristic of Monilinia spp. Fungi causing brown rot of pome and stone fruits in Poland. Eur. J. Plant Pathol. 135:855-865.

Posada, D., and Crandall, K. 1998. Modeltest: Testing the model of DNA substitution. Bioinformatics 14:817-818.

Ronquist, F., and Huelsenbeck, J. 2003. MrBayes 3: Bayesian phylogenetic inference under mixed models. Bioinformatics 19:1572-1574.

Swofford, D. L. 2000. PAUP: Phylogenetic Analysis Using Parsimony. Sinauer Associates, Sunderland, MA.

van Brouwershaven, I. R., Bruil, M. L., van Leeuwen, G. C. M., and Kox, L. F. F. 2010. A real-time (TaqMan) PCR assay to differentiate Monilinia fructicola from other brown rot fungi of fruit crops. Plant Pathol. 59:548-555.

van Leeuwen, G. C. M., Baa Yen, R. P., Holb, I. J., and Jeger, M. J. 2002 Distinction of the Asiatic brown rot fungus Monilia polystroma sp. Nov. From M. fructigena. Mycol. Res. 106:444-451.

van Leeuwen, G. C. M., and van Kesteren, H. A. 1998. Delineation of the three brown rot fungi of fruit crops (Monilinia spp.) on the basis of quantitative characteristics. Can. J. Bot. 76:2042-2050.

Vasić, M., Duduk, N., Ivanovic, M. M., Obradovic, A., and Ivanovic, M. S. 2012 First report of brown rot caused by Monilinia fructicola on stored apple in Serbia. Plant Dis. 96:456.

Wang, Y. X., Wang, G., Zeng, Q. C., and Zhang, Z. Y. 1998. Studies on the investigation and integrated control of brown rot disease of peach (Monilia sp.). Yunnan Nong Ye Da Xue Xue Bao 13:29-32.

White, T. J., and Bruns, T. 1990. Amplification and direct sequencing of fungal ribosomal RNA genes for phylogenetics. Pages 315-322 in: PCR Protocols: A Guide to Methods and Applications. M. A. Innis, D. H. Gelfand, J. J. Sninsky, and T. J. White, eds. Academic Press, New York.

Yin, L. F., Chen, G. K., Chen, S. N., Du, S. F., Li, G. Q., and Luo, C. X. 2014. First report of brown rot caused by Monilia mumecola on Chinese sour cherry in Chongqing Municipality, China. Plant Dis. 98:1009.

Yin, L. F., Chen, S. N., Chen, G. K., Schnabel, G., Du, S. F., Chen, C., Li, G. Q., and Luo, C. X. 2015. Identification and characterization of three Monilinia species from plum in China. Plant Dis. 99:1775-1783.

Zhu, X. Q., Chen, X. Y., and Guo, L. Y. 2011. Population structure of brown rot fungi on stone fruits in China. Plant Dis. 95:1284-1291.

Zhu, X. Q., Chen, X. Y., Luo, Y., and Guo, L. Y. 2005. First report of Monilinia fructicola on peach and nectarine in China. Plant Pathol. 54:575.

Zhu, X. Q., and Guo, L. Y. 2010. First report of brown rot on plum caused by Monilia polystroma in China. Plant Dis. 94:478.

Zhu, X. Q., Guo, L. Y., and Chen, X. Y. 2008. Diseases of peach and nectarine in China. Asian Australas. J. Plant Sci. Biotechnol. 2:42-49.

Zhu, X. Q., Zheng, H. H., Fang, Y. L., and Guo, L. Y. 2014. A method to induce significant production of conidia from Monilinia fructigena, Monilia polystroma, and Monilia yunnanensis. Australas. Plant Pathol 43:531-533. 